\title{
MILKING THE PLAINS: MOVEMENT OF LARGE DAIRY OPERATIONS INTO SOUTHWESTERN KANSAS*
}

\author{
LISA M. B. HARRINGTON, MAX LU, and DAVID E. KROMM
}

\begin{abstract}
Western Kansas has an historical identification with cattle, with a focus on cattle ranching and more specifically since the 1950s, beef-cattle feedlots. Since the mid-1990s large dairy operations have moved into southwestern Kansas. Today more than twenty large dairies house more than 70,0oo milk cows. These operate as confined feeding operations similar to beef-cattle feedlots. Regional advantages for the dairy industry include affordable land with wide-open space, local residents' cattle- and dairy-friendly attitudes, and other factors. Regional promoters have actively recruited dairies, and a dairy-business support system has emerged. The prospects for continued expansion of dairies in southwestern Kansas are unclear; despite the locational advantages and the possibility that the industry may continue to relocate here, as did the cattle-feeding industry several decades ago, further moves into the area may depend on continued resources availability and additional infrastructure development. Keywords: agriculture, dairy, geographical restructuring, Great Plains, High Plains, Kansas.
\end{abstract}

$\mathrm{O}$ ver the past century and more, the Great Plains developed an identity as a region of rangeland, cattle, and wheat. In public perception the major agricultural landscapes and products of the plains states are combined with a history of periodic drought and with real and supposed problems of depopulation (Popper and Popper 1987; Hudson 1996; Rathge and Highman 1998; Johnson and Rathge 2006; see also White 1994). Through history, inhabitants of the High Plains have relied on animals to a large extent, including the use of bison by Native Americans. Cattle ranching by Euro-American settlers began in the 1800s. After more than a century of cattle raising on ranches and as a limited part of small family farms, large cattle feedlots began to appear in the 1960s (Bussing and Self 1981). Large confined hogfeeding operations have appeared in some localities, with extraordinary expansion in the Oklahoma panhandle during the 1990s (Hart and Mayda 1997). Large-scale dairying began in southwestern Kansas in the mid-1990s. The industry has seen expansion, and both state agencies and regional promoters express confidence that dairying will continue to grow in importance for western Kansas (Forno 2008a, 2008b). The drought-prone land of bison and cattle ranching, which explorers labeled "the Great American Desert" in the early 180os, ${ }^{1}$ has surprisingly become the home of tens of thousands of Holstein milk cows.

The dairy industry is seeing a significant geographical shift in the United States (Cross 2006). Dairies are relocating from other states to the southern High Plains in

* This research was supported by the National Aeronautic and Space Administration, through the Association of American Geographers' Global Change in Local Places project (NAGW-4932), and by a National Science Foundation grant for Infrastructure to Develop a Human-Environment Regional Observatory (HERO) Network (1920KSU-NSF-8052).

3. Dr. Harrington is a professor of geography at Kansas State University, Manhattan, Kansas 66506, where DR. Lu is an associate professor and Dr. Кгомм is a professor emeritus of geography. 
search of wide-open space and bigger profit margins. Despite a steady decline in dairy numbers nationwide, dairying is on the rise in the southern High Plains. Southwestern Kansas experienced particularly rapid growth between 1995 and 2005 and now contains one of the most significant clusters of dairy operations in the Great Plains. In the early 1990 s this part of Kansas, though famous for its large-scale beef feedlots and meatpacking operations, had no commercial dairies. Today very large commercial dairies, with milk-cow capacities in the thousands, also dot the landscape. In the fourteen southwesternmost counties the estimated population of milk cows exceeds 73,000 (NASS 2009). Based on this impressive growth, southwestern Kansas has been called dairy's "new frontier" (Mooney 2002). The Kansas Department of Agriculture expects continued strong growth: "The dairy industry, in Kansas and most of the nation, is changing. Kansas is recognized as one of the top dairy growth states. The relatively dry climate in the southwest, the ability to obtain the desired quantity and quality of water and the abundant dairy feed supply has contributed to this growth. Expect this growth to continue. Farm numbers will decrease but farm size (cow numbers and milk production) will increase at a greater rate" (KDA 2006).

The emergence of megadairies is the most recent major event in southwestern Kansas's changing agribusiness landscape, one that is viewed favorably by both local economic development organizations and residents. In this article we document the phenomenon in southwestern Kansas and examine the driving forces behind the expansion of large dairy-feeding facilities into the southern High Plains.

\section{SOUTHWESTERN Kansas}

Our research is based on the High Plains-Ogallala Human-Environment Regional Observatory (HPO HERO) area (Harrington, Lu, and Harrington 2002, 2009; Harrington 2005). The core study area for the HPO HERO includes the nineteen counties in the southwestern corner of Kansas (Figure 1), with a total area of 15,880 square miles (Harrington, Lu, and Harrington 2009, 270). For some purposes, the southern fourteen counties of the area are the focus of analysis: They constitute the southwestern Kansas agricultural statistical area used for combined enumeration. ${ }^{2}$

The weather and climate regimes of the High Plains display a high level of yearto-year variability and extremes (Skaggs 1978; Rosenberg 1986). Precipitation is highly variable but generally averages less than 21.5 inches per year. Due to commonly subhumid conditions, reliable crop production requires either growing crops that require low levels of moisture or using irrigation to provide sufficient crop moisture (Kromm and White 1992).

The economy of southwestern Kansas relies on agriculture and agricultural support services. The area includes the top five counties in agricultural sales for the state, with more than $\$ 3.4$ billion in revenue in 2007 (ERS 2009b). Just these five counties account for nearly 24 percent of the Kansas agricultural sales total, and the other fourteen counties in the HPO HERO area contribute almost 35 percent of the state total. For decades, livestock, particularly beef cattle, have far outnum- 


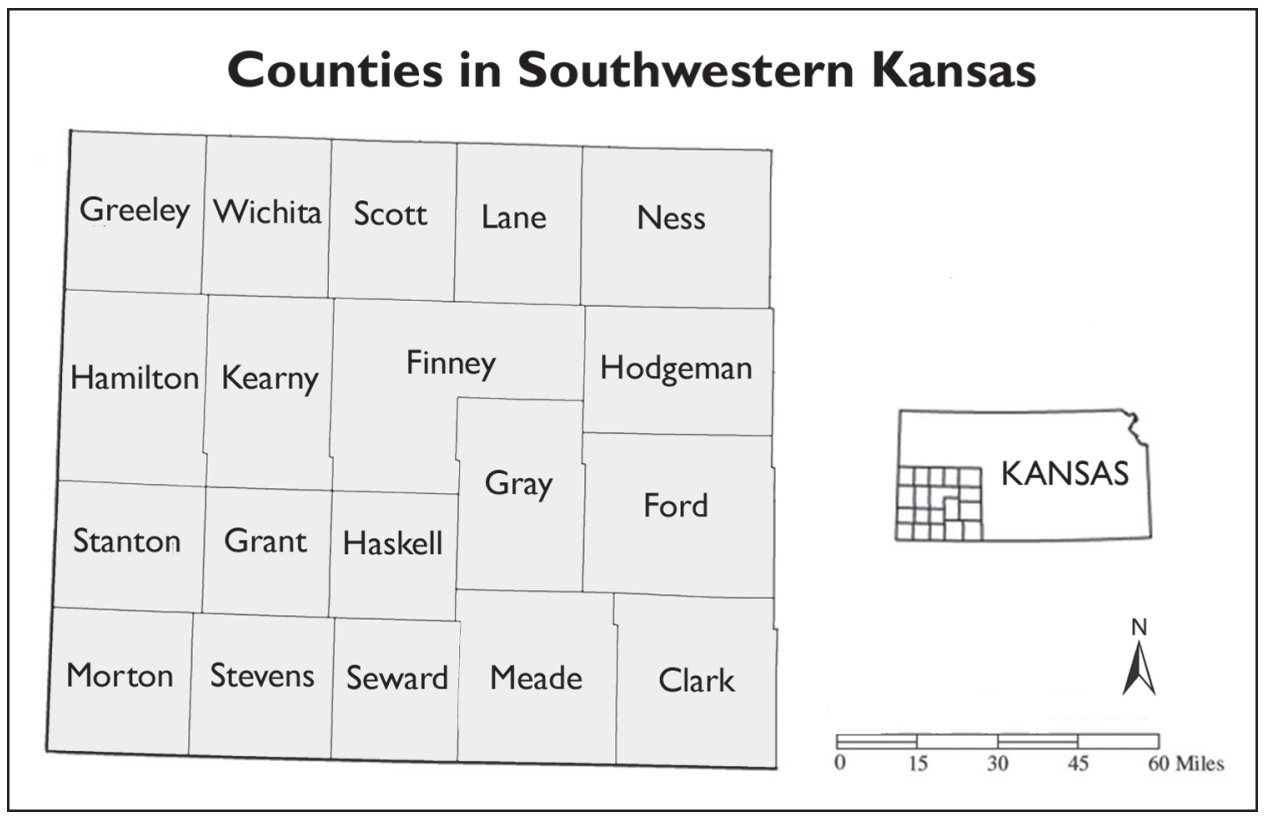

FIg. 1-Nineteen counties in southwestern Kansas constitute the High Plains-Ogallala HumanEnvironment Regional Observatory study area. (Cartography by Lisa Harrington)

bered the human population; at the dawn of the twenty-first century, an estimated 156,000 people and more than 2.5 million beef cattle inhabited the HPO HERO area (Harrington, Lu, and Harrington 2009). The region is real "cattle country" in terms of its high level of beef production and the importance of cattle to southwestern Kansas's economy and history.

\section{Traditional Areas of U.S. Dairying Concentration}

Although settlers took milk cows with them as they moved westward, dairy farming and production in the United States remained concentrated in the Northeast and Upper Midwest / Great Lakes region until about 1990 (Figure 2). The U.S. Dairy Belt was identified as running from the Upper Midwest to New York State (Hartshorne 1935; Durand 1940, 1951). Wisconsin was central to dairying and became known as "America's Dairyland" by the 1920s (Cross 2001). In 1920 Wisconsin became the state with the greatest number of dairy cows, followed by New York and Minnesota (Larson and others 1923). Wisconsin remained the top dairy state until the 1990s, when California overtook it in both the number of milk cows and dairy production (Cross 2001). Although the focus of dairy production remained in the Dairy Belt until the 1990s, small dairy farms and dairies still were still scattered around the country, serving local areas for the most part until at least 1970.

The geographical pattern of dairy farming experienced its first major change in the second half of the twentieth century, when milk production increased rapidly in the West, especially California, in part because of increased demand generated by rapid population growth. In 1993 California became the largest dairy state in the 
United States. Were it a state, Tulare County would rank as one of the top milkproducing states in the nation (CDFA 2003).

\section{The Western Model of Dairying}

The development of more intensive farm operations helped California move to the top among milk-producing states. Industrialized dairying had its beginnings in Southern California in the 1920s, when Dutch immigrants introduced corral feeding. Rather than pasturing cattle, farmers concentrated the cows in pens and brought feed to them, as is now the common practice in beef-cattle feedlots or feed yards (a form of concentrated animal-feeding operation, or CAFO). Dutch and Portuguese farmers created a comprehensive dairy industry, and regional economies of scale emerged in Los Angeles County with concentration of dairy cows, hay and grain production, milk collection, and related services-veterinarians and specialized financial institutions, for example-in the area (Hart 2003).

Although traditional, self-sufficient dairy farms continued to dominate in the northern dairy areas, economic forces, technological innovations, changes in milkproduction systems, and specialization led to significant restructuring of dairying in the West. Following World War II, suburban growth, rising land prices, and social pressures due to the undesirable aspects of dairying odors and waste pressured farmers to leave the area. However, when they did relocate, they were able to move with a significant amount of capital and the ability to develop larger operations in more rural locations because of the high land prices commanded by their original farms (Guthey, Gwin, and Fairfax 2003; Hart 2003). As dairy farming in California grew in size, machinery and equipment substituted for labor and confined feeding

FIG. 2-In 1919 the Dairy Belt stretched from the Northeast to the Upper Midwest. Source: Larson and others 1923,318 .

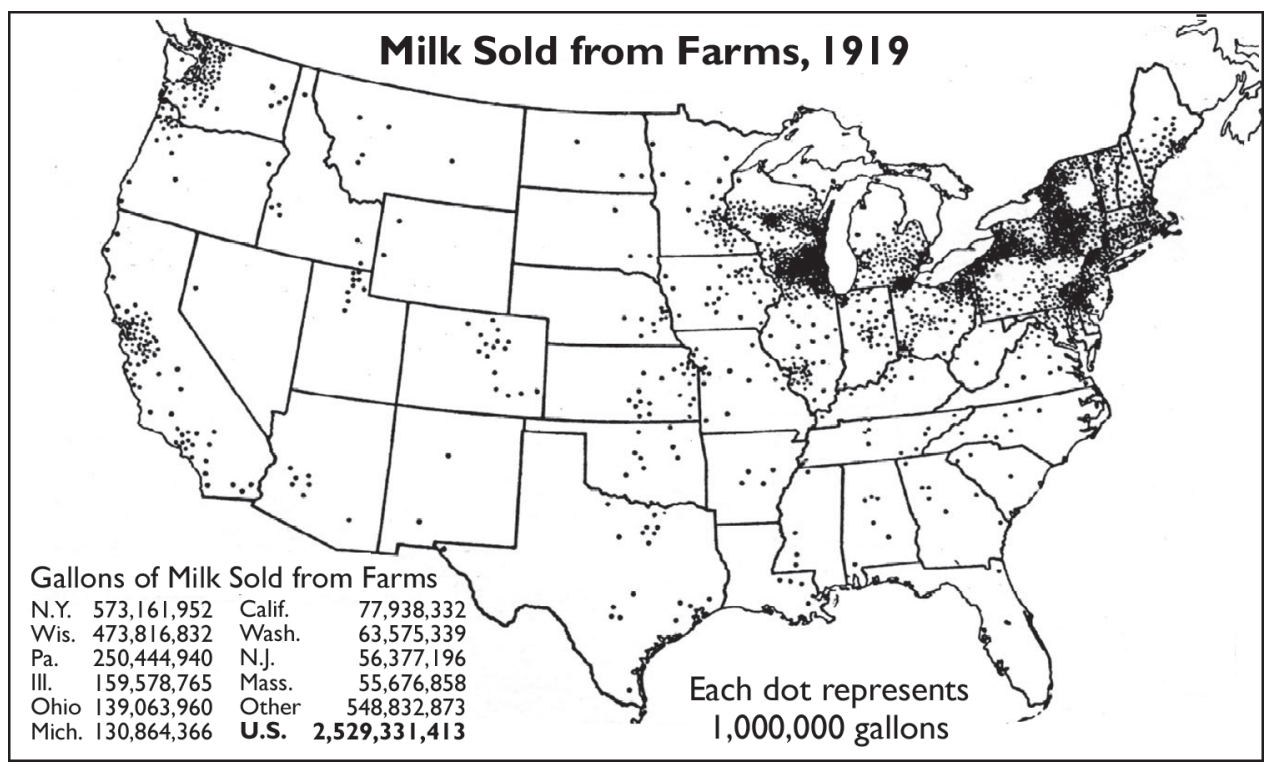


replaced pasture-based cow management. Dairy farms, replacement heifer raising, and feed- and fodder- crop production are single-purpose operations in new versions of dairy landscapes (Blayney 2002). Characterizing the transformation, Harry Schwarzweller and Andrew Davidson wrote that "profound differences are observed-huge sharp contrasts-between the traditional, small dairy with its craftbased mode of production and the more modern, megadairy with its factory mode of production" $(2000,6)$.

A "western model" of dairying emerged, characterized by large units frequently housing as many as 3,000 milk cows, high capital investment, and reliance on the purchase of feed grains and animals (Peterson 2002). Technological innovation facilitated the changes in the form of on-farm refrigerated bulk milk tanks, efficient milking parlors, new systems of housing animals, and improved feed- and water-handling systems (Blayney 2002). Milk production is seen as an investment opportunity, although individuals and families continue to own and operate commercial dairy farms.

Douglas Harper classified American dairy farms as being in a state of "early mechanization" from the 1850 s to World War II, but this early mechanization was based primarily on the use of reapers, early gas-powered tractors, and manure spreaders (2000). He considered more modern-1950-present-dairies as having reached "advanced mechanization," although he commented that dairy farms in the United States appeared to be reaching a fourth phase, spelling "the 'end of history' for the small farm" (p. 13). The transition of production from the Dairy Belt to California and rising production in other states has involved the creation of larger, more industrialized operations. The shift to large industrialized operations, coincident with the regional reorganization of dairying, though perhaps not meaning the "end" of small dairy farms, is certainly related to Harper's bleak assessment.

\section{The Movement of Dairying to Southwestern Kansas}

California, Wisconsin, New York, Pennsylvania, and Minnesota have been the top five milk-producing states since the mid-1970s. However, increasing quantities of milk production in southern Idaho, eastern New Mexico, eastern Washington, and southwestern Kansas "have contributed to the changing national landscape of milk production" (Short 2004, ii). This shift to increasing milk production in nontraditional states is a part of the recent expansion of western-style dairies beyond California. According to Sara Short, "Milk producers in the West had a significant cost advantage over producers in other regions in 2000 because their operations were much larger. Operations with 500 or more milk cows had significantly lower total operating and ownership costs, indicative of the economies of size experienced by larger operations" (2004, i). The traditional dairy region has been depicted as losing market share due to a lack of movement toward more industrialized production (Hart 2003), although the old Dairy Belt also is seeing a trend toward larger operations (Sebastian 1998).

Small dairy herds and family milk cows were common around the country in the first half of the twentieth century, and small dairy herds and creameries in 


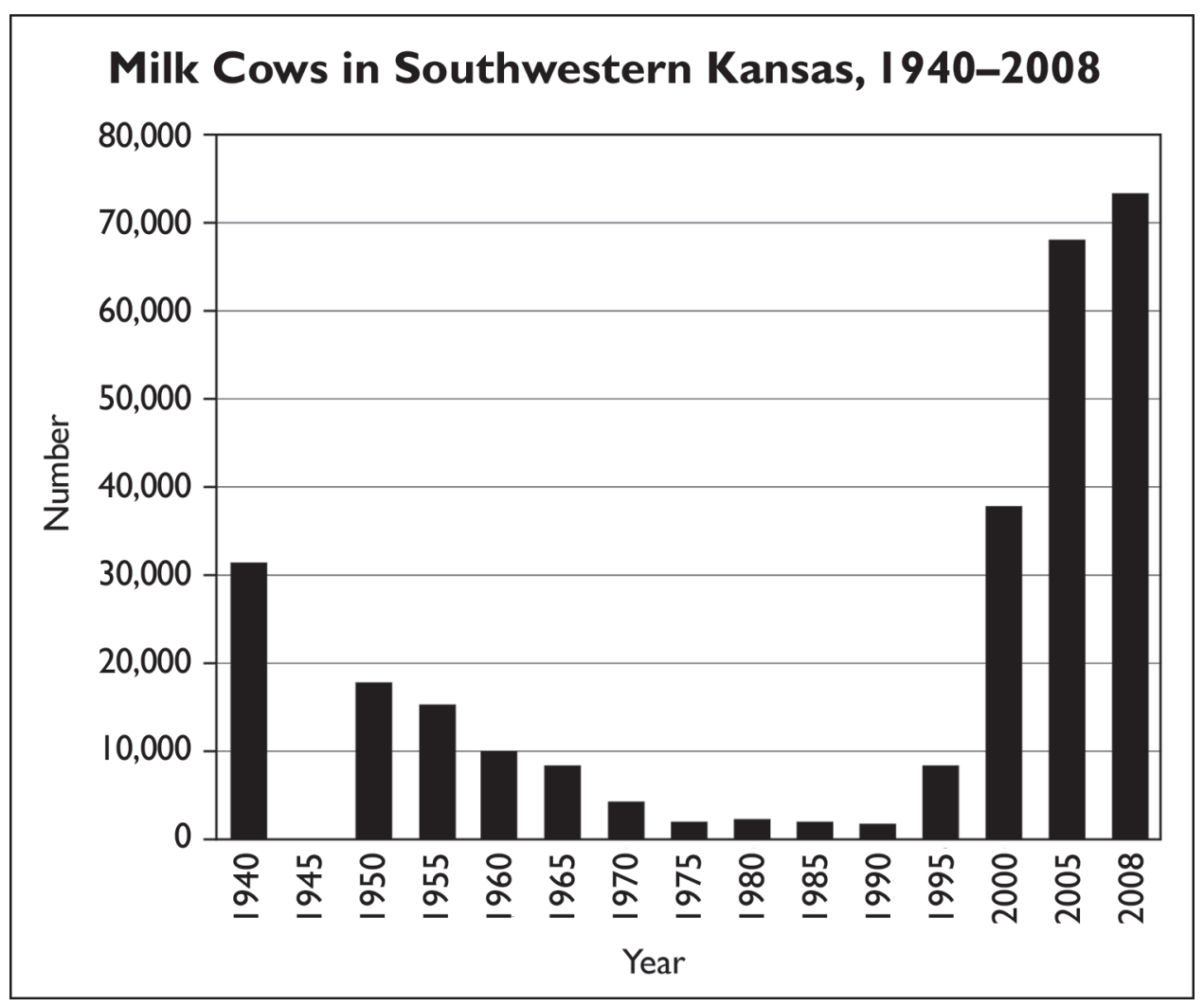

FIG. 3-Changes in the numbers of milk cows in a fourteen-county statistical area in southwestern Kansas, 1940-2008. Dates of estimates vary, from 1 January to a yearly average number; the datum for 1945 is missing. Sources: NAss; KsBA. (Graph by Lisa Harrington)

southwestern Kansas provided dairy products for the local population. As traditional mixed farming phased out with movement toward greater specialization in the mid-to-late twentieth century, the total number of milk cows continued to drop (Figure 3). In 1940, the fourteen-county southwestern Kansas statistical area was home to more than 31,000 milk cows. The number dropped precipitously, to 18,000 in 1950, 10,000 in 1960, and 4,300 in 1970. Even in the three counties with the region's largest human populations-Finney, Ford, and Seward-milk-cow numbers fell to only about fifty to a few hundred animals. The total number of dairy cattle in southwestern Kansas remained very low from about 1975 to 1990. The 1990 began a period of rapid expansion, with tremendous growth between 1995 and 2005.

The first western-style megadairy moved to the region-Seward County-from Southern California in 1994. Today, estimates range from more than 69,000 milk cows to a capacity of well over 100,000 dairy cows in facilities licensed by the Kansas Department of Health and Environment (KDHE). More than twenty very large dairies are, or were, in operation (Figure 4), some of them combined with beef operations. State licensing records indicate one small operation of 120 cows; the next 


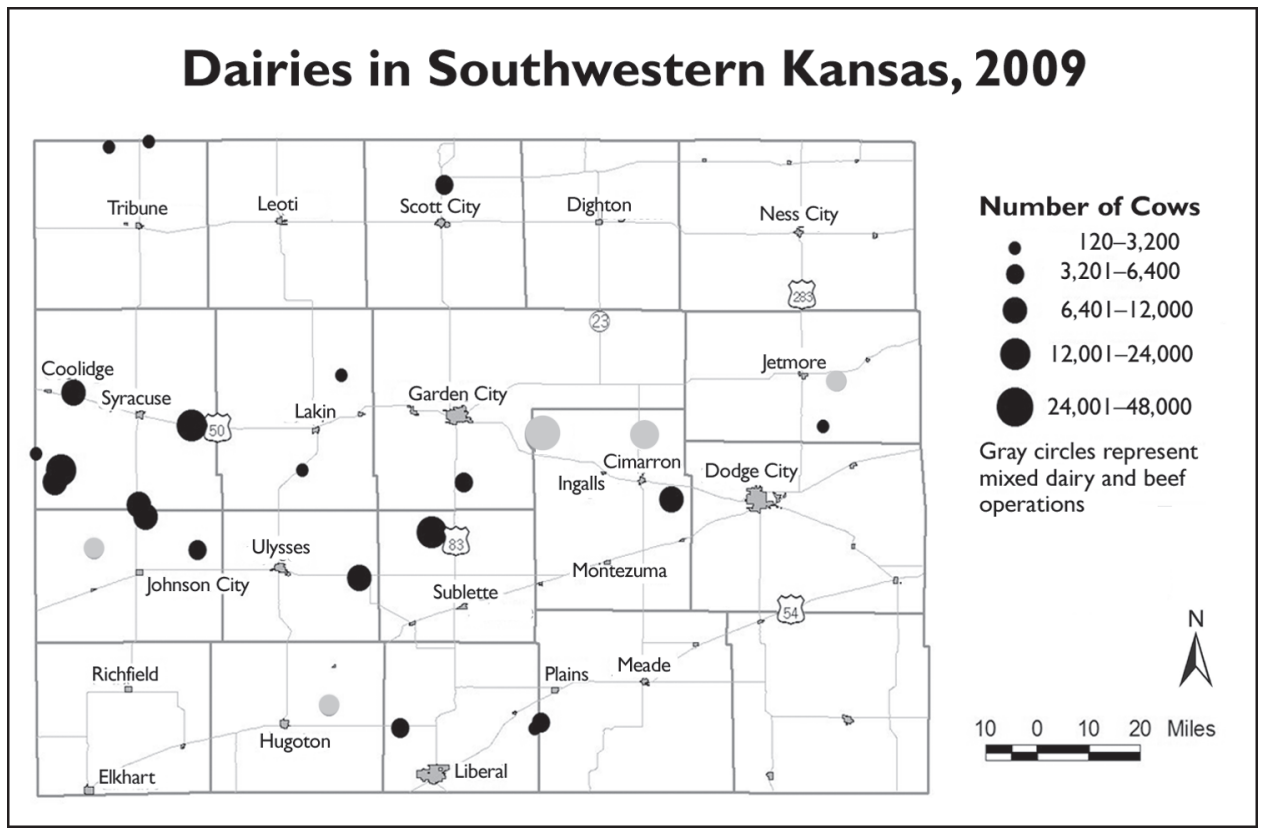

FIG. 4-Dairies in southwestern Kansas, 2009. Size is based on state permitted capacity. Five dairies, indicated in gray, including the two largest, are combination dairy and beef operations, leading to inflation of some dairy sizes on this map. Source: Permits provided by the Kansas Department of Health and Environment, Bureau of Water, May 2009. (Cartography by Max Lu)

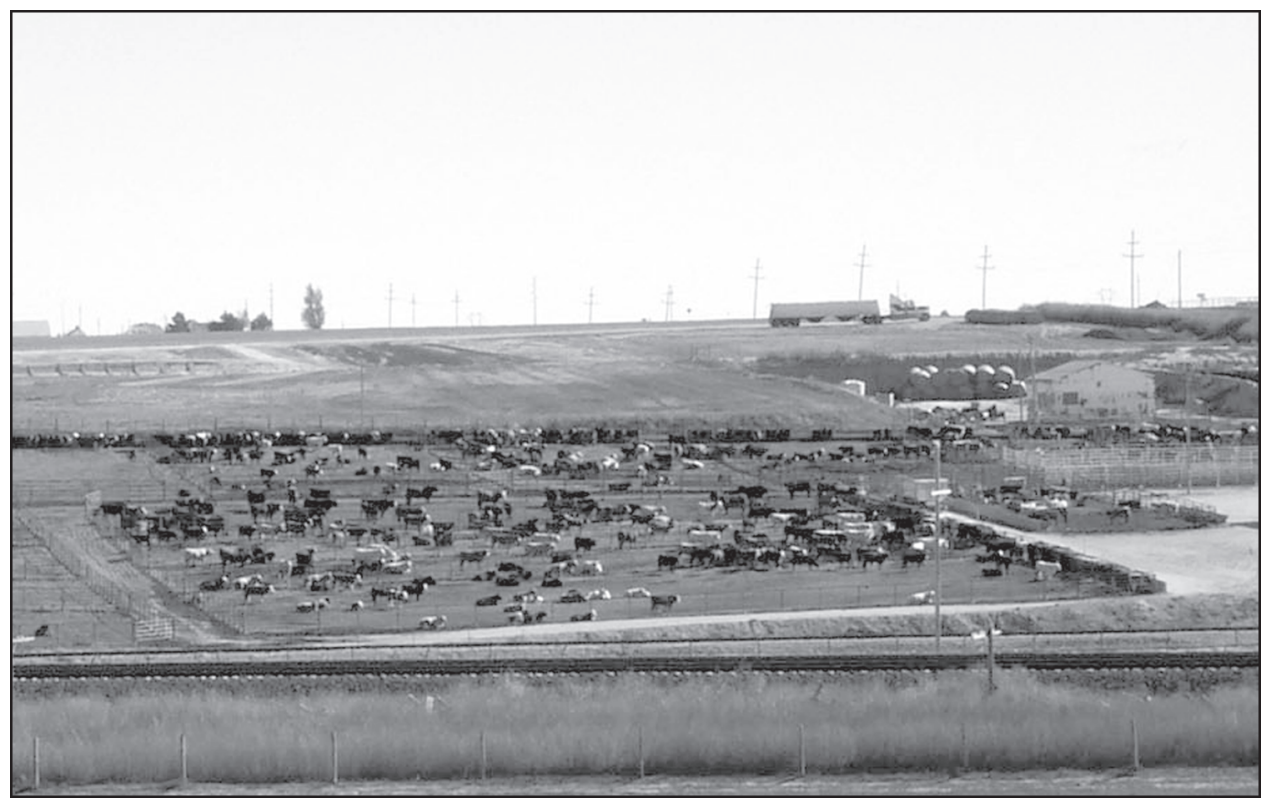

FIG. 5-Portion of a concentrated animal feeding operation (CAFO), or feedlot, on the outskirts of Dodge City, Kansas. (Photograph by Lisa Harrington, November 2000) 
smallest is 699 animals, and the remaining range upward from 2,420. According to 2009 KDHE permitting records, the two largest strictly dairy operations have the capacity to house 12,000 head. ${ }^{3}$ In 2009 the largest dairy milked 8,000 cows. The number of dairies continues to grow: Another dairy with the capacity to milk more than 6,00o head opened in Gray County in late 2008 (Wetmore 2008). Southwestern Kansas-the national center for cattle feeding and beef packing-thus is also becoming an important source of fluid milk. The growth momentum has been so strong that some dairy operators believe that what happened to the cattle industry in the 1960s and 1970s is now occurring in the dairy industry: a regional shift of the activity from traditional core areas to the High Plains.

The dairies in southwestern Kansas are completely new facilities, built from the ground up. Most cows have been shipped in, either from farther west or from the Great Lakes States. Many of the dairy operations are family enterprises that relocated from the dairy states or are jointly owned by local and outside investors. Some crop farmers in the region have invested in dairies as a means of diversifying.

Although the region has been a center of beef-cattle feeding, with numerous large CAFOs, dairy feeding, production, and management require more specialized skills than does beef production and, hence, some changes to managerial workforce experience and training. In jointly owned dairies the management teams are generally from established dairies in the U.S. West-mainly California or New Mexico-or in Europe. Employees often come from western dairies. The dairies often are heavily reliant on Hispanic workers, including American citizens, documented workers from Mexico and Central America, and-likely_ "improperly documented" immigrants (Yale 2008, 50). The meatpacking plants in southwestern Kansas have relied on Hispanic workers for nearly thirty years (Broadway 2000; Stull and Broadway 2001; Broadway and Stull 2006).

\section{Characteristics of Dairy Facilities}

The dairies in southwestern Kansas are large-scale, confined feeding operations similar to beef-cattle feedlots (Figure 5), although the number of animals is much smaller. ${ }^{4}$ Unlike traditional dairy farms, which are largely self-sufficient in forage requirements, these large dairies focus on animal husbandry and purchase most feed locally. Because of the equipment and buildings needed for milk production, the capital investment for dairies is much larger than for beef-cattle feedlots.

Dairy operations in southwestern Kansas house their cows in either drylots or freestall barns, and milking is done two or three times daily in separate but adjacent milking parlors. A drylot dairy is built much like a traditional beef CAFO, with large pens and feed and water troughs or tanks (Figure 6). They are common in southwestern Kansas and other states with mild winters and low precipitation, such as Southern California, New Mexico, or Arizona. The drylot provides 500-700 square feet per lactating cow and may utilize windbreaks to protect livestock from the harsh winter weather (Smith and others 2000). Operators clean cows in wash pens before they enter the milking parlors (Figure 7). 


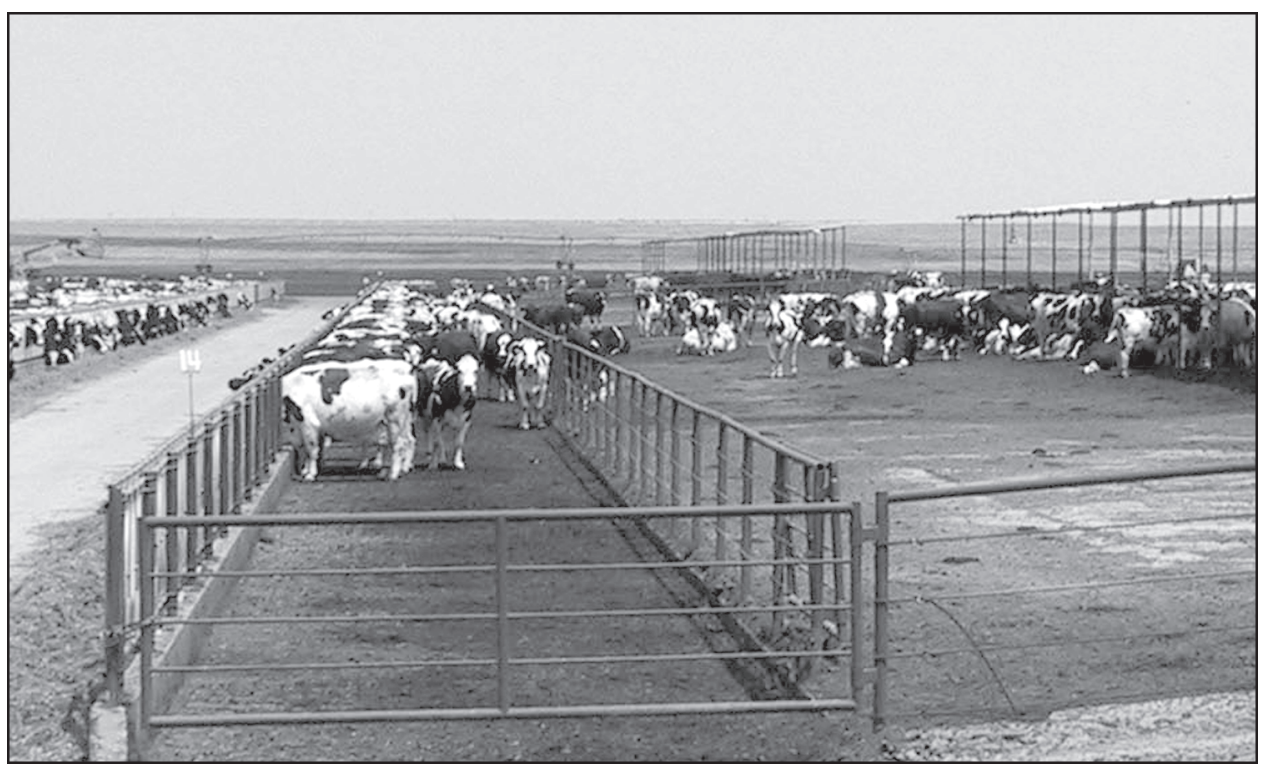

FIG. 6-This drylot dairy in Stevens County, Kansas, includes shade structures-on the right in this photograph-for the cattle. (Photograph by Lisa Harrington, June 2002)

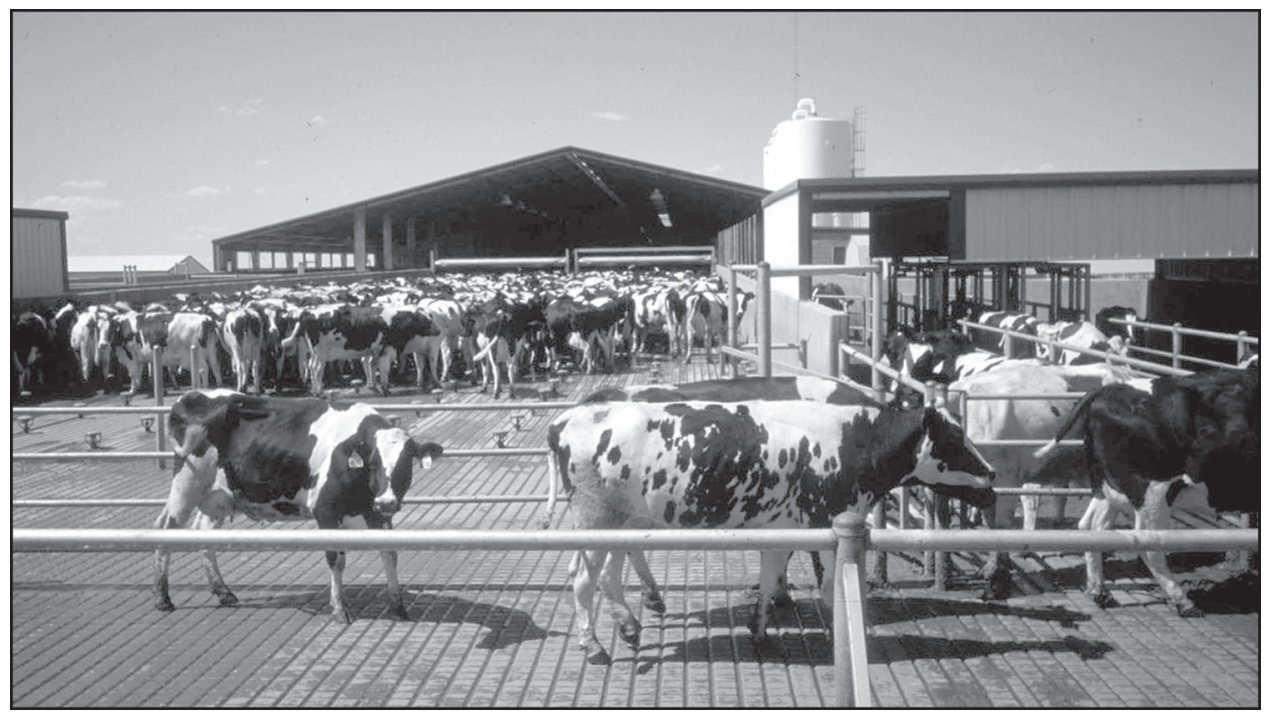

Fig. 7-In this 6,00o-head drylot dairy, cows move into chutes that lead to milking parlors (seen in the background). The owner of Royal Dairy, in Gray County, is a longtime western Kansas farmer and feedlot operator. (Photograph by David Kromm, June 2004) 


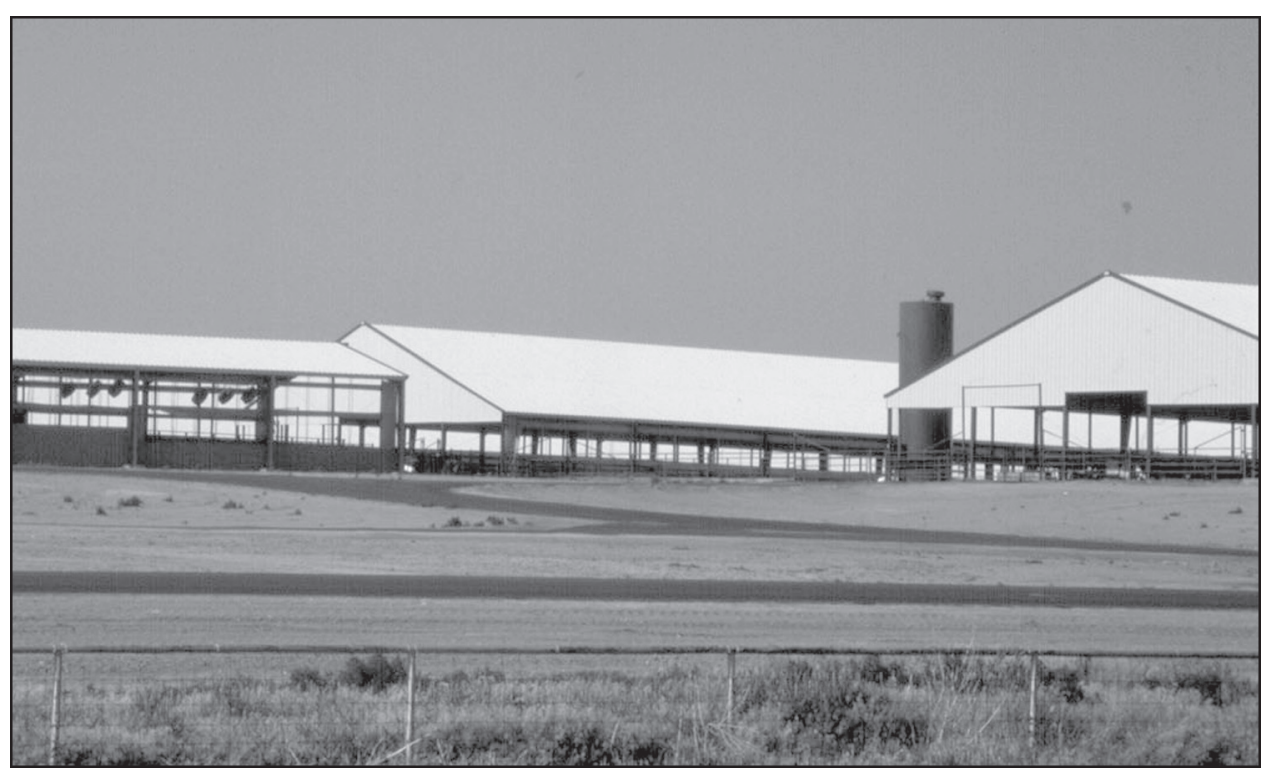

FIG. 8-The open sides that characterize most freestall barns, including these at the Santa Fe Dairy in Grant County, Kansas, provide ventilation. (Photograph by David Kromm, June 2004)

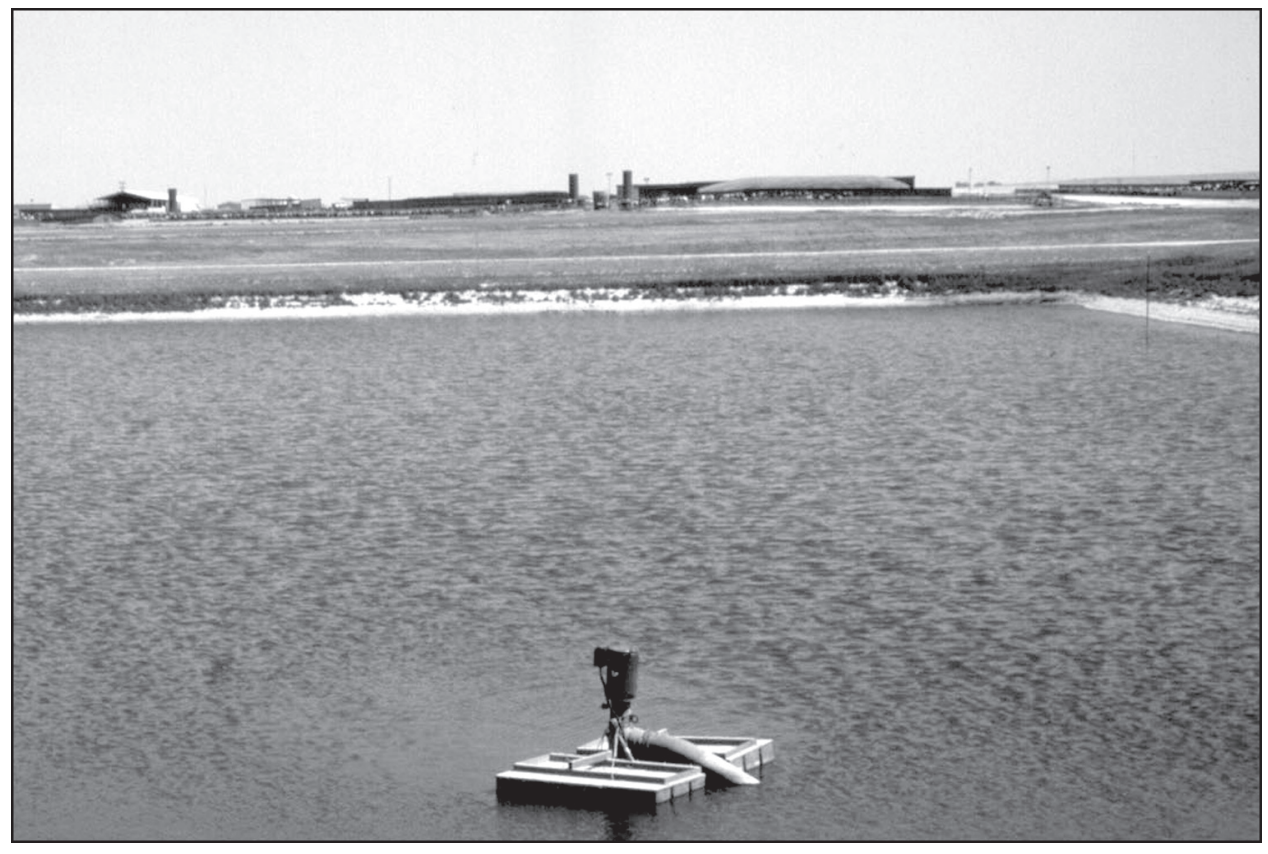

Fig. 9-Syracuse Dairy's wastewater lagoon, Hamilton County, Kansas. (Photograph by David Kromm, June 2004) 
Freestall housing reduces the impact of weather by providing a stall with a dry bed, often of sand or sawdust, for each animal. With milking parlors connected to the barns, cows in freestall operations spend virtually their entire productive lives indoors. Housing for heifers is separate, usually in a building with smaller stalls (Schoonmaker 2002). Freestall barns normally are open sided for ventilation (Figure 8). Although their configuration varies somewhat, stalls typically run along both sides of a linear building. Between the lines of stalls is a concrete floor that is regularly flushed with water (Bailey 1997; Smith and others 2000). Construction costs are higher per cow for freestall barns than for drylots, and maintaining clean beds for the animals is labor intensive, but milk production also is higher.

In both drylot and freestall dairies liquid manure from dairy cows runs off into lagoons, where it is stored and settled (Figure 9). In addition, washing with water helps to flush the waste. Wastewater from the lagoon and freshly pumped water are blended for application to fields for irrigation and fertilizer (Bailey 1997).

At milking time the cows walk single file into a milking parlor, where they stand in gated quarters waiting to be milked. Simultaneous milking of two rows of twenty or more cows is common; Royal Dairy milks dual rows of sixty, for example (Wetmore 2008). Workers clean the cows' teats with water or disinfectant and attach milking machines that automatically detach after depleting the milk (Harper 2000). The fresh milk is first heated to kill bacteria-pasteurized-and then cooled for shipping in tanker trucks. The whole process resembles an assembly line, supporting the label of "factory farm" given to the megadairies. At present, milk processing occurs outside southwestern Kansas. Most marketing is through Dairy Farmers of America, the largest dairy cooperative in the United States, which ships much of the milk toward areas southeast of the HPO HERO region. A new cheese plant, however, recently opened in Dalhart, Texas, south of the Kansas dairy-expansion area. Hilmar Cheese Company, based in California, opened its Texas operation in September 2007, with the company announcing expansion plans by August 2008 (Welch 2008). These are currently under way. As in southwestern Kansas, the Texas panhandle, where Dalhart is located, has seen extremely rapid growth in large dairy operations-from about 23,000 cows in 2000 to more than 125,000 in 2006 (Hoard's Dairyman staff 2007). The growth of dairies in the region has attracted cheese production, and the establishment of the cheese plant is contributing to the attractiveness of the region for large diary operations.

\section{Driving Forces for Expansion of Dairying into SOUTHWESTERn Kansas}

The recent emergence of southwestern Kansas as a dairy-producing region appears to be a textbook example of push and pull forces at work. The push comes from urban expansion pressures on dairy land in California, limited space for dairy enlargement in the older dairy regions of the Northeast and Upper Midwest, less than ideal climate-for example, cold winters in Minnesota, increasing feed and operating costs, and more stringent environmental regulations in many areas. ${ }^{5}$ Relatively 
favorable conditions for dairy growth and, perhaps more important, concerted regional efforts to bring dairying to the region exert the pull. Among potential destinations for dairy growth, southwestern Kansas and the larger High Plains region have been particularly successful in their pull.

Traditional dairies in the Northeast and north-central United States were smallscale family operations. Continual restructuring of dairying in the United States since the 1970 s has led to a steady decline in the total numbers of dairy cows and farms, even as average dairy-herd size and milk production have increased (Bailey 2000). In order to survive, many dairies have increased their scale of operation. Due to relatively dense populations and early land divisions that resulted in smaller landholdings, dairy expansion is not always easily accommodated in the traditional dairy states. Population pressures against dairy expansion also come in the form of urban sprawl. As population expands and urbanization encroaches on farmland, land values soar; in some cases leases to dairy operators are not renewed because of landowners' intent to sell to developers. In urbanizing areas, dairy owners have to deal with local residents' complaints about the odor, and in many cases dairy operators are facing tightening environmental regulations. Dairies have been forced to relocate farther and farther from core production regions. When relocating in the same state is not feasible, moving to a sparsely populated location, such as the High Plains, becomes a logical alternative. Expansion and further industrialization accompany relocations (Gilbert and Wehr 2003; Hart 2003).

Southwestern Kansas possesses several advantages for the dairy industry. Land for waste management and for expansion, water availability and quality, feed costs, and public perception-or acceptance-are among the important considerations that dairy operators rate highly in deciding on a location (Winkler Stirm and St-Pierre 2003). As pointed out in the promotional material prepared by the Western Kansas Rural Economic Development Alliance (wKREDA) (n.d.b), the area "is ideally suited to the dairy industry" because of its "abundance of irrigated farmland, wide open spacing [sic], a semiarid climate, stable economic base, and low operational costs." The price, quality, and availability of feed grains are central to dairy expansion, and the High Plains has had the lowest grain prices among the dairy regions, with hay and silage costs being competitive as well (Burchfield and Linderoth 1999). Although corn prices rose rapidly in the mid-200os, with higher fuel prices and moves toward greater ethanol production, they seem to be stabilizing. The U.S. Department of Agriculture Economic Research Service projects that the use of corn for ethanol will show a much-reduced growth rate and that corn prices will fall in the early to mid-2010s (ERS 2009a).

Affordable land and labor have also been elements in dairy expansion. Western Kansas offers space with the capability for expansion and for handling large amounts of manure. Its sparse population ensures that urban expansion and transportation congestion will not hinder dairy development. The basic labor needs of the dairy industry are met by Hispanic immigrants who were initially attracted to the area by employment opportunities in the region's meatpacking industry (Broadway 1990, 
1994). Although fifteen of the sixteen small counties, each with less than 8,000 population in 2000, in the HPO HERO have continued to lose residents since 2000, the three larger counties-centered on Garden City, Dodge City, and Liberal-grew between 2000 and 2008 (U.S. Census Bureau 2010). The Hispanic population in southwestern Kansas grew not only in the three most populous counties but also in all but three of those that were shrinking overall (IPSR 2009a). Unemployment rates during 2009 remained lower than the state and national averages (IPSR 2009b).

Dairy cows perform well in environments with low humidity, but dairy operations require substantial water. In addition to drinking water for cows, water is important for managing waste and maintaining the animals' health in extreme climates (Peterson and Dhuyvetter 2001). For example, water mist may be applied to lactating dairy cows in summer to cool them and reduce the adverse effects of heat stress on milk production. Not only is low humidity typical of western Kansas, but southwestern Kansas also has an adequate amount of water available from the High PlainsOgallala aquifer system to support dairy expansion for several decades, at least in some parts of the region. Dairy farms generally require about ten times as much water per animal as does a beef-cattle feedlot, but dairies generate a greater dollar value per unit of water used than do feedlots or crop farms. They also use lowercapacity pumps than those that are needed for crop irrigation and spread the use of their water more evenly throughout the year than does an irrigated farm.

Last but not least, the cattle-friendly attitude of people in southwestern Kansas makes the region attractive to the dairy industry. Local residents generally accept animal agriculture, for they are accustomed to large beef-cattle feedlots and the odor from them. Locals see dairying as a natural extension of the region's cattlefeeding industry and a good way to diversify the local economy, add jobs, and bring in additional revenue. Large-scale dairies fit easily into the existing landscape and culture. The infrastructure built for the beef industry and the many companies that serve beef operations in the region can also support dairy operations. As other dairy areas increasingly face open hostility to megadairies from homeowners, recreationists, and environmentalists, Kansas becomes all the more attractive as a new location for dairy expansion and relocation.

Determined to seize the opportunity, communities in western Kansas have been actively recruiting dairies. Financial incentives are part of the effort. Low-interest loans and tax breaks are offered to investors to start a dairy. The state of Kansas also assists with developmental grants and permit processing. Regional banks have taken a leadership role in assisting with the financing of new dairies. A dairy-business support system has emerged (Figure 10), which includes specialized services required by dairies, as well as more general support required by any animal-based business, such as veterinary services. State and regional organizations actively seek dairy expansions and relocations from the West, the Great Lakes States, and the Northeast. Regional development organizations have played an important role in bringing the dairy industry to western Kansas. The WKREDA, for example, has made dairy expansion a top priority (see, for example, WKREDA n.d.b). Informational 


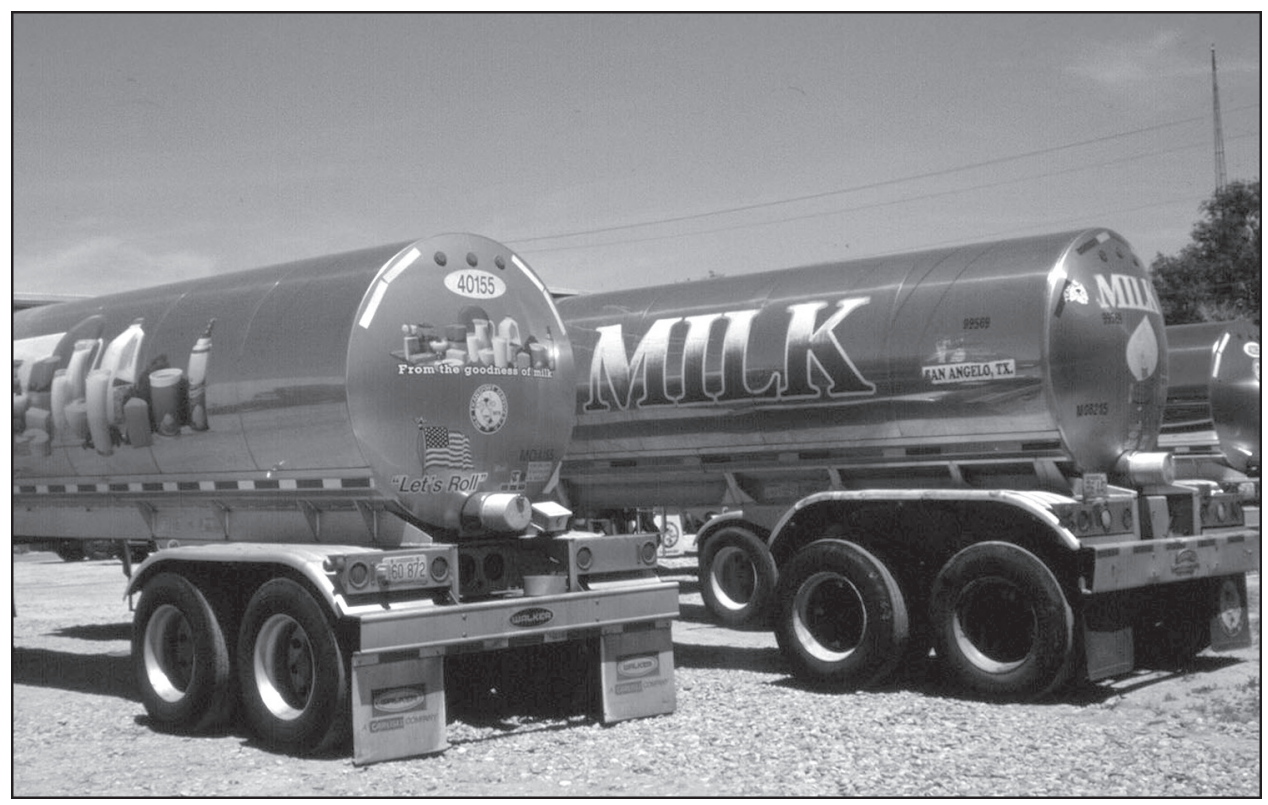

FIG. 10-Milk trucks in southwestern Kansas. (Photograph by David Kromm, June 2004)

booths have been set up at national and even international dairy trade events held in the United States, such as the Californian Farm Equipment Show in Tulare, California, and the annual World Dairy Expo in Madison, Wisconsin. The organization identifies and courts out-of-state dairies that have been "zoned" out or have to move or shut down for various reasons. The WKREDA group even flies interested dairymen to western Kansas to visit the region. Locally, Hamilton County has been holding annual Southwest Kansas Dairy Days in Syracuse, similar to the Beef Days held in Garden City, to promote dairies. The efforts seem to have paid off. Industrial dairies in western Kansas have originated as offshoots or relocations of operations from several other states (see, for example, Peter 2002; Latzke 2010). Efforts to attract additional dairies continue through the Kansas Dairy Initiative-a cooperative project of the state Department of Commerce and WKREDA-and successful selection of a southwestern Kansas dairy as a featured virtual tour site at the 2010 World Dairy Expo (KDC 2010).

In spite of the benefits touted for establishing dairies in southwestern Kansas, some economic concerns have arisen. Transportation costs are a major issue in the dairy industry (Winkler Stirm and St-Pierre 2003; Roesler 2007). Fluctuations in fuel prices, particularly with high prices as seen in 2007-2008, for example, may deter further expansion in the region. Additionally, the dairy industry has been under economic stress nationally, with high production and relatively low prices leading to a late 2009 announcement of a new U.S. Department of Agriculture Dairy Economic Loss Assistance Payment program, as well as to other Department of Agriculture support through dairy-product purchasing under various programs during 2009. Although such concerns are likely to at least slow or create a pause in 
dairy development in Kansas, no signs indicate that current dairy operations are in imminent danger.

\section{Economic Impacts of Dairies in Southwestern Kansas}

One source states that the estimated annual economic impact of a 2,500-head dairy, which is small by regional standards, amounts to \$13 million in revenue (WKREDA n.d.a). The dairy industry contributes to the economy both directly and indirectly. Direct impacts include jobs created and the sales of milk and calves. One estimate indicates that dairies hire on average one person for every 100-150 cows (Burchfield and Linderoth 1999). The dairy industry in southwestern Kansas therefore may have added as many as 700 people to the local payroll. The new jobs provided by dairies give some small communities in western Kansas a new lease on life. Indirect benefits are realized through purchases of supplies, services, feed, and replacement heifers. Each dairy operation relies on many thousands of dollars' worth of corn, silage, and hay each year. The dairies in southwestern Kansas will certainly increase the demand for corn, hay, and alfalfa produced in the region and therefore benefit crop farmers. Because of the demand for high-protein alfalfa to assure productive cows, the dairies encourage growing of this relatively high-value crop. However, the need to bring in feed from other agricultural areas, such as Iowa or Nebraska, is likely to increase. This, of course, will mean additional costs for milk producers, but corn has been brought in to supplement local supplies for beef production for some time, so importing feed is already a regional practice.

Because milk produced in southwestern Kansas is not processed locally, much of the value added by processing dairy products is not realized in the region. If a milk-processing plant, such as a cheese factory, were to be built in the area, the total economic benefits would certainly be much higher. Such an undertaking has been on the agenda of local development agencies, but the number of cows needs to reach about 100,000-150,000 to support a processing facility, and the capacity of dairy operations in the region has only recently attained this threshold.

Some researchers and members of the public believe that larger farm operations spend less locally, and thus contribute less to community stability, than do small farms (Foltz, Jackson-Smith, and Chen 2002; Foltz and Zeuli 2005). Higher transaction costs for distant purchases, however, lead all dairies to buy locally whenever possible (Foltz, Jackson-Smith, and Chen 2002). The megadairies of southwestern Kansas purchase local feed for their cows and support dealers for dairy-feed supplements and equipment as well as veterinary and bulk milk-shipping services. Regional firms build and repair dairy facilities. Most important, in the absence of commercial dairy farms prior to the 1990s, the establishment of megadairies in western Kansas means the establishment of additional dairy-oriented economic activities in the region and the growth of other activities that can extend their services to the dairy industry. Even though, by some estimates, large dairies spend less locally than do small dairies, large dairies contribute more locally than do no dairies. 


\section{Potential Concerns}

Although our focus has been on the process and factors related to recent and rapid establishment of large dairy operations in southwestern Kansas, potential drawbacks of megadairy expansion also deserve comment. First, industrial-model dairies exert additional pressures on the nonrenewable water resources of the region. As mentioned above, the per-cow use of water for dairy operations is much higher than for beef-cattle production. The smaller size of dairy operations, as compared with beef CAFOs, means that dairies are no worse than beef feedlots in terms of water use. Although the groundwater resources in parts of the region are sufficient to support the large dairies into the near future, the status of the aquifer and its depletion have been, and continue to be, a concern (Kromm and White 1992; White and Kromm 1995). Water is being managed at higher levels of irrigation-use efficiency but with the knowledge that it eventually will be economically inaccessible for crops. Sustainability of use of the aquifer is not in question-it is known to be unsustainable (Harrington 2005; Harrington, Lu, and Harrington 2009).

The likely future need for feed shipments into the area also may be a drawback. With increasing transportation costs and a push for more ethanol production, causing high corn prices in 2007 and 2008-and contributing to increases in U.S. milk prices in those years-the possible need to bring in feed as well as ship out milk or processed milk products may become a deterrent to continued expansion. Cornbased ethanol production in the region may affect the availability of feed, but it also creates a useful by-product, distiller's grains, which are fed to livestock as part of their food mix.

In addition to heavy use of resources, other criticisms of CAFos have been raised. In 2008 the Union of Concerned Scientists issued a report critical of all types of CAFos, including dairy operations. Criticisms were based largely on the externalities of largeanimal operations and concentrations of these operations in particular regions (Gurian-Sherman 2008). Such externalities include various forms of pollution, although resource consumption might be included as well. The Union of Concerned Scientists report also found cause for concern based on the level of subsidization-often indirect-of CAFOs, as opposed to livestock operations of a less "industrialized" form.

Related to economic and environmental costs associated with transportation, good cause also exists for for moves toward locally produced foods.

Although local foods are desirable, regions that traditionally have focused on quantity agricultural production are highly likely to continue to be important for the United States. Southwestern Kansas, though seeing some diversification in agricultural production, likely will remain dependent on agriculture and associated activities for its economic base. The concern continues to be which types of agriculture can be supported in the long term, given a declining water-resource base in much of the region. That said, some areas still have significant groundwater and should therefore be able to support large dairies well into the future. Until perhaps the 2020s, other pressures related to differences between production costs and in- 
come are likely to cause more disruption to the dairy industry in southwestern Kansas than are shortages of groundwater.

Longer-term considerations not directly related to economics, particularly in the 30-100-year time frame, are likely to relate to climate change and to reductions in groundwater availability to the point that the availability of desirable cattle feed is reduced, if not the availability of sufficient water for dairy operations. Climatechange models tend to indicate increased temperatures, increased rates of moisture loss, and possibly lower precipitation over the High Plains (Harrington, Lu, and Harrington 2009). The duration, intensity, and frequency of droughts may change, intensifying demands on groundwater resources. With respect to potential effects of climate change specifically on the southwestern Kansas dairy industry, the longerterm future is cloudy indeed. ${ }^{6}$

\section{Prospects}

Southwestern Kansas has been referred to as the "New Frontier" for dairying (KPS 2003). Some local leaders believe that, just as the movement and consolidation of cattle feeding in the United States brought that industry to the area about forty years ago, the restructuring of dairying will favor the region now. Geographical shifts in milk production are occurring parallel to structural change (Peterson 2002, 15). Improved bulk handling, refrigeration, and transportation reduce the costs of moving milk in space and time. Hikaru Peterson suggested that the recent growth of dairying in western Kansas may trigger an agglomeration effect that supports future growth (2002).

The national demand for milk products continues to rise because of the consumption of cheese in convenience foods such as "pizza, tacos, fast-food sandwiches, and packaged snack food" (Peterson and Dhuyvetter 2001, 2). The relatively long distance to market is still a significant disadvantage for Kansas dairies. At present, milk produced in southwestern Kansas is shipped to fluid milk bottlers outside the region, although the establishment of cheese production in the Texas panhandle may offer another destination. Local milk processing substantially reduces transportation costs. As shown in Texas, processing capacity has added to the pull of the larger region for additional dairy operations and has local economic benefits.

Structural change in the American dairy industry favors the megadairy. Because of the land, space, feed, and water advantages southwestern Kansas offers, largescale dairying is likely to maintain its presence in the region over the short term, potentially growing further when markets stabilize. The competitive position is strengthened by the long-standing livestock and animal-raising culture that readily accepts megadairies as an extension of the traditional farm economy and by the existing infrastructure and services. Questions arise, however, when considering the long-term limitations in a region where surface water is lacking and groundwater resources are being depleted. Other factors also may change the current balance of locational benefits. In addition to water availability, there is potential for energy 
costs, market conditions, and environmental change to effect a shift from net positive conditions to net negative locational considerations in southwestern Kansas. For the time being, the pull of the region seems to be holding.

\section{Notes}

1. The map compiled following the 1819-1820 journey led by Major Stephen Long prominently labeled the midsection of the country as "desert." Today the High Plains is more accurately described as generally "subhumid," but highly variable annual rainfall is the reality.

2. State agricultural statistics are reported by county, except in cases where such reporting may be a concern for privacy issues; for example, when a county has only one relevant farm operation. Where data are missing for this reason, the statistical district total still includes the missing counties. District 30, Southwest Kansas, is used here.

3. The largest operation overall has a combined dairy- and beef-cattle capacity of 48,0oo head.

4. A large beef-cattle feedlot may confine 60,000 to 100,000 or more animals.

5. As the editors of Dairy Today noted, "Strike up a conversation with dairy producers from different states at any national meeting and each will claim their state's environmental regulations and bureaucracies are the toughest in the country" (2007). California dairies, they say, operate under arguably the most stringent air- and water-quality regulations in the country.

6. The same is true for a great number of human activities and natural systems.

\section{REFERENCES}

Bailey, K. W. 1997. Marketing and Pricing of Milk and Dairy Products in the United States. Ames: Iowa State University Press.

- 2000. Consolidation in the Dairy Industry: There Is a Future for Small Family Farmers. Paper presented at the Twin Cities Agricultural Issues Round Table, Minneapolis, Minn., 25 October.

Blayney, D. P. 2002. The Changing Landscape of U.S. Milk Production. USDA Statistical Bulletin 978. [www.ers.usda.gov/publications/sb978/sb978.pdf].

Broadway, M. J. 1990. Meatpacking and Its Social and Economic Consequences for Garden City, Kansas in the 1980s. Urban Anthropology 19 (4): 321-344.

- 1994. Beef Stew: Cattle, Immigrants and Established Residents in a Kansas Beefpacking Town. In Newcomers in the Workplace: Immigrants and the Restructuring of the U.S. Economy, edited by L. Lamphere, A. Stepick, and G. Grenier, 25-43. Philadelphia: Temple University Press.

- 200o. Planning for Change in Small Towns or Trying to Avoid the Slaughterhouse Blues. Journal of Rural Studies 16 (1): 37-46.

Broadway, M. J., and D. D. Stull. 2006. Meat Processing and Garden City, KS: Boom and Bust. Journal of Rural Studies 22 (1): 55-66.

Burchfield, G., and S. Linderoth. 1999. More Milk on the Plains: Region Sees Growth as Dairy-Industry Shift Continues. Dairy Producer, December. Formerly at [www.moomilk.com/archive/dairy _p_39.htm].

Bussing, C. E., and H. Self. 1981. Changing Structure of the Beef Industry in Kansas. Transactions of the Kansas Academy of Sciences 84 (4): 173-186.

CDFA [California Department of Food and Agriculture]. 2003. California Dairy Statistics and Trends, 2003 Mid-Year Review. Sacramento: California Department of Food and Agriculture, Dairy Marketing Branch.

Cross, J. A. 2001. Change in America's Dairyland. Geographical Review 91 (4): 702-714. . 2006. Restructuring America's Dairy Farms. Geographical Review 96 (1): 1-23.

Dairy Today editors. 2007. Bragging Rights. Dairy Today, 8 November. [www.agweb.com/DairyToday /Article.aspx?id=139315].

Durand, L., Jr. 1940. Dairy Region of Southeastern Wisconsin and Northeastern Illinois. Economic Geography 16 (4): 416-428.

. 1951. The Lower Peninsula of Michigan and the Western Michigan Dairy Region: A Segment of the American Dairy Region. Economic Geography 27 (2): 163-183. 
ERS [Economic Research Service]. 2009a. Corn: Market Outlook; USDA Feed Grain Baseline, 200918. Briefing Rooms (U.S. Department of Agriculture, Economic Research Service), 27 March. [www.ers.usda.gov/briefing/Corn/2009baseline.htm].

- 2009b. State Fact Sheets: Kansas. Data Sets (U.S. Department of Agriculture, Economic Research Service), 9 December. [www.ers.usda.gov/statefacts/KS.htm].

Foltz, J. D., and K. A. Zeuli. 2005. The Role of Community and Farm Characteristics in Farm Input Purchasing Patterns. Review of Agricultural Economics 27 (4): 508-525.

Foltz, J. D., D. Jackson-Smith, and L. Chen. 2002. Do Purchasing Patterns Differ between Large and Small Dairy Farms? Econometric Evidence from Three Wisconsin Communities. Agricultural and Resource Economics Review 31 (1): 28-38.

Forno, C. 2008a. Experts Say SW Kansas Could Be Part of Dairy Industry's Future. Dodge City Daily Globe, 28 August. [http://nl.newsbank.com/nl-search/we/Archives?p_action=doc\&p_docid $=122 \mathrm{DE} 5$ C5D817FFDo\&p_docnum $=1 \&$ p_theme=gatehouse\&s_site=DCDG\&p_product=DCDG].

- 2008b. Crash Course in Dairy Operations. Dodge City Daily Globe 29 August. [http://nl .newsbank.com/nl-search/we/Archives?p_action=doc\&p_docid=122E38E8990712Fo\&p_docnum $=1 \& p \_$theme $=$gatehouse\&s_site $=$DCDG\&p_product $=$DCDG] .

Gilbert, J., and K. Wehr. 2003. Dairy Industrialization in the First Place: Urbanization, Immigration, and Political Economy in Los Angeles County, 1920-1970. Rural Sociology 68 (4): 467-490.

Gurian-Sherman, D. 2008. CAFOs Uncovered: The Untold Costs of Confined Animal Feeding Operations. Cambridge, Mass.: Union of Concerned Scientists.

Guthey, G. T., L. Gwin, and S. Fairfax. 2003. Creative Preservation in California's Dairy Industry. Geographical Review 93 (2): 171-192.

Harper, D. 2000. Requiem for the Small Dairy: Agricultural Change in Northern New York. In Dairy Industry Restructuring: Research in Rural Sociology and Development, vol. 8, edited by H. K. Schwarzweller and A. P. Davidson, 13-45. New York: JAI.

Harrington, L. M. B. 2005. Vulnerability and Sustainability Concerns for the U.S. High Plains. In Rural Change and Sustainability: Agriculture, the Environment and Communities, edited by S. J. Essex, A. W. Gilg, and R. Yarwood, 169-184. Cambridge, Mass.: CABI Publishing.

Harrington, L. M. B., M. Lu, and J. A. Harrington Jr. 2002. Human Adaptability to Environmental Change: Development of an Assessment Protocol. Papers and Proceedings of the Applied Geography Conferences 25: 269-275.

- 2009. Fossil Water and Agriculture in Southwestern Kansas. In Sustainable Communities on a Sustainable Planet: The Human-Environment Regional Observatory Project, edited by B. Yarnal, C. Polsky, and J. O’Brien, 269-291. New York: Cambridge University Press.

Hart, J. F. 2003. The Changing Scale of American Agriculture. Charlottesville: University of Virginia Press.

Hart, J. F., and C. Mayda. 1997. Pork Palaces on the Panhandle. Geographical Review 87 (3): 396-400.

Hartshorne, R. 1935. A New Map of the Dairy Areas of the United States. Economic Geography 11 (4): $347-355$.

Hoard's Daiyman staff. 2007. Construction Well Underway at Hilmar Texas Cheese Plant. Hoard's Dairyman, February, w40.

Hudson, J. C. 1996. The Geographer's Great Plains. Kansas State University, Department of Geography, Occasional Publications in Geography, No. 1. Manhattan, Kansas.

IPSR [Institute for Policy and Social Research]. 2009a. Hispanic Population in Kansas, by County, 1990 and 2000 Kansas Statistical Abstract Enhanced Online Edition. University of Kansas, Institute for Policy and Social Research. [www.ipsr.ku.edu/ksdata/ksah/population/2pop28.pdf].

- 2009b. Unemployment Rates in Kansas, by County, 2004-2009, Annual Averages. Kansas Statistical Abstract Enhanced Online Edition. University of Kansas, Institute for Policy and Social Research. [www.ipsr.ku.edu/ksdata/ksah/employment/8emp5.pdf].

Johnson, K. M., and R. W. Rathge. 2006. Agricultural Dependence and Changing Population in the Great Plains. In Population Change and Rural Society, edited by W. A. Kandel and D. L. Brown, 197-217. Dordrecht, Netherlands: Springer.

KDA [Kansas Department of Agriculture]. 2006. Kansas Dairy Industry. Kansas Department of Agriculture. [www.ksda.gov/dairy/content/122].

KDC [Kansas Department of Commerce]. 2010. Kansas Dairy Selected to Give Virtual Farm Tour. DairyInKansas.com. 14 May. [www.dairyinkansas.com/2010/05/royal-farms-dairy-of-garden-cityselected-to-give-virtual-farm-tour-at-world-dairy-expo/]. 
KPS [Kansas Prosperity Summit]. 2003. The "New Frontier." Kansas Prosperity Summit, Southwest Regional Plan, September 2003. [http://kdoch.state.ks.us/KDOCHdocs/AD/summit_sw_action _plan.pdf].

Kromm, D. E., and S. E. White, eds. 1992. Groundwater Exploitation in the High Plains. Lawrence: University Press of Kansas.

KSBA [Kansas State Board of Agriculture]. Various years. Kansas Farm Facts and Biennial Reports. Topeka: Kansas State Board of Agriculture.

Larson, C. W., L. M. Davis, C. A. Juve, O. C. Stine, A. E. Wright, and others. 1923. The Dairy Industry. In Yearbook of the Department of Agriculture, 1922, 281-394. Washington, D.C.: Government Printing Office.

Latzke, J. M. 2010. Family Dairy Remembers Priorities. High Plains Journal [Dodge City], 10 May. [www.hpj.com/archives/2010/may10/may24/0507DairyMACOjmlsr.cfm].

Mooney, R. 2002. Dairy's New Frontier. Elite Producer [supplement to Dairy Today], November/December, $2-4$.

NASS [National Agricultural Statistics Service]. Various years. Kansas Farm Facts. Topeka: U.S. Department of Agriculture, National Agricultural Statistics Service, Kansas Field Office.

Peter, M. L. 2002. Dairies Look to Kansas for Room to Grow. Kansas State University Research and Extension News, 16 May. [www.ksre.ksu.edu/news/sty/2002/dairy_McCarty10402.htm].

Peterson, H. H. 2002. Geographic Changes in U.S. Dairy Production. Paper presented at the Annual Meeting of the American Agricultural Economics Association, Long Beach, California, 28-31 July.

Peterson, H. H., and K. C. Dhuyvetter. 2001. “Got Cows?” Trends in the Kansas Dairy Industry. Paper prepared for the Risk and Profit Conference, Manhattan, Kansas, 16-17 August.

Popper, D. E., and F. J. Popper. 1987. The Great Plains: From Dust to Dust. Planning 53 (6): 12-18.

Rathge, R., and P. Highman. 1998. Population Change in the Great Plains: A History of Prolonged Decline. Rural Development Perspectives 13 (1): 19-26.

Roesler, S. 2007. In Spite of Reduced Producer Numbers, Pork, Dairy Industries Grow. Farm \& Ranch Guide, 7 December . [www.farmandranchguide.com/articles/2007/12/o7/ag_news/livestock_news /livio.txt].

Rosenberg, N. J. 1986. Adaptations to Adversity: Agriculture, Climate, and the Great Plains of North America. Great Plains Quarterly 6 (3): 202-217.

Schoonmaker, K. 2002. Promote Heifer Free-Stall Use. Dairy Herd Management, 11 January. [www .dairyherd.com/directories.asp?pgID=724\&ed_id=1435].

Schwarzweller, H. K., and A. P. Davidson. 2000. Introduction: Research Agendas and Foci of Concern in Dairy Industry Restructuring. In Dairy Industry Restructuring: Research in Rural Sociology and Development, vol. 8, edited by H. K. Schwarzweller and A. P. Davidson, 1-12. New York: JAI.

Sebastian, R. M. 1998. Upper Midwest Marketing Area: Study of Upper Midwest Producers by Size Range of Delivery. Staff Paper 98-02. Minneapolis, Minn.: Federal Milk Market Administrator's Office.

Short, S. D. 2004. Characteristics and Production Costs of U.S. Dairy Operations. USDA Statistical Bulletin 974-6. [www.ers.usda.gov/publications/sb974-6/sb974-6.pdf].

Skaggs, R. H. 1978. Climatic Change and Persistence in Western Kansas. Annals of the Association of American Geographers 68 (1): 73-80.

Smith, J. F., J. P. Harner III, M. J. Brouk, D. V. Armstrong, M. J. Meyer, and others. 2000. Relocation and Expansion Planning for Dairy Producers. Manhattan: Kansas State University, Cooperative Extension Service.

Stull, D. D., and M. J. Broadway. 2001. "We Come to the Garden" . . Again: Garden City, Kansas, 1990-2000. Urban Anthropology 30 (4): 269-300.

U.S. Census Bureau. 2010. Kansas. State and County QuickFacts. Last revised 22 April. [http://quickfacts .census.gov/qfd/states/2000o.html].

Welch, K. 2008. Hilmar Boosts Dalhart Plant. Amarillo.com. 8 August. [www.amarillo.com/stories /080808/new_news12.shtml].

Wetmore, B. 2008. Western Kansas Hosts Fourth Dairy University. High Plains / Midwest Ag Journal, 13 October. [www.hpj.com/archives/2008/octo8/oct13/WesternKansashostsfourthDai.cfm?title =Western\%2oKansas\%2ohosts\%2ofourth\%2oDairy\%2oUniversity].

White, S. E. 1994. Ogallala Oases: Water Use, Population Redistribution, and Policy Implications in the High Plains of Western Kansas, 1980-1990. Annals of the Association of American Geographers 84 (1): $29-45$. 
White, S. E., and D. E. Kromm. 1995. Local Groundwater Management Effectiveness in the Colorado and Kansas Ogallala Region. Natural Resources Journal 35 (2): 275-307.

Winkler Stirm, J. E., and N. R. St-Pierre. 2003. Identification and Characterization of Location Decision Factors for Relocating Dairy Farms. Journal of Dairy Science 86 (11): 3473-3487.

WKREDA [Western Kansas Rural Development Alliance]. N.d.a. Want to Add \$26,000,00o to Your Local Community? Would You Settle for Adding \$13,000,00o? Discover Western Kansas.com. [www .wkreda.com/Document.aspx?id=1156].

- N.d.b. An Invitation to Dairy in Western Kansas. Discover Western Kansas.com. [www .discoverwesternkansas.com/Document.aspx?id=10200].

Yale, B. 2008. Congress Fails to Reform Immigration: How That Changes the Law for Dairy Farmers. In Proceedings, 2008 High Plains Dairy Conference, Albuquerque, N.Mex., 49-56. [www.highplainsdairy .org/2008/12\%20Yale.pdf]. 